\title{
Tobacco chippers seeking assistance for smoking cessation: a case series
}

\author{
Tobacco chippers em busca de auxílio para parar de fumar: série de casos
}

Gabriel Natan Pires, ${ }^{1}$ Luciana Rizzieri Figueiró, ${ }^{2}$ Maristela Ferigolo, ${ }^{3}$

Helena Maria Tannhauser Barros ${ }^{4}$ Denise Conceição Mesquita Dantas ${ }^{3}$

\begin{abstract}
Objective: To describe a series of cases of tobacco chippers (TCs) who sought assistance for smoking cessation.

Description of cases: We describe the case of three TCS who participated in a free quit-smoking support group. Smokers answered self-administered questionnaires covering sociodemographic data, smoking history, nicotine dependence, perceived health status, and motivational stages. Of the 183 smokers enrolled in the program, three $(1.6 \%)$ were considered TCs. All three were women and reported alcohol use, although at low frequencies. Two of them reported the presence of potentially tobacco-related disease. All TCs presented light nicotine dependence and reported difficulties quitting smoking. All dropped out after the first group meeting.

Comments: This study describes a subgroup of smokers not extensively described in the literature: TCs seeking assistance for smoking cessation, with some degree of nicotine dependence, and who do not adhere to regular group therapy. Interventions aimed at this population may be an interesting strategy for smoking cessation.
\end{abstract}

Keywords: Tobacco chippers, smoking, dependence, cessation, case series.

\section{Resumo}

Objetivo: Descrever uma série de casos de tobacco chippers (TCs) que buscaram auxílio para cessação do hábito de fumar. Descrição dos casos: São descritos três casos de TCs que participaram de um grupo de apoio terapêutico a tabagistas. Os participantes responderam questionários autoaplicados que incluíam questões sobre dados sociodemográficos, histórico de tabagismo, dependência à nicotina, estado de saúde percebido e estágios motivacionais. Dos 183 tabagistas inscritos no grupo, três $(1,6 \%)$ foram considerados TCs. Todos os três casos eram mulheres e relataram o uso de álcool, embora em frequências baixas. Duas relataram a presença de doenças potencialmente relacionadas ao uso do tabaco. Todas apresentavam baixos níveis de dependência à nicotina e relataram dificuldades em parar de fumar. Todas desistiram do tratamento após a primeira sessão. Comentários: Este estudo descreve um subgrupo de fumantes ainda não muito explorado na literatura: TCs que buscam auxílio para cessação do hábito de fumar, apresentam algum grau de dependência à nicotina e não aderem à terapia de grupo tradicional. Intervenções direcionadas especificamente a essa população podem ser uma estratégia interessante para a cessação do hábito de fumar.

Descritores: Tobacco chippers, tabagismo, dependência, abandono do uso de tabaco, série de casos.

\footnotetext{
${ }^{1}$ MSc. Bachelor's degree in Biomedicine, Universidade Federal de São Paulo (UNIFESP), São Paulo, SP, Brazil. Serviço Nacional de Informações e Orientações sobre a Prevenção do Uso Indevido de Drogas (VIVAVOZ). ${ }^{2}$ MSc. Bachelor's degree in Biomedicine, Universidade Federal de Ciências da Saúde de Porto Alegre (UFCSPA), Porto Alegre, RS, Brazil. VIVAVOZ. ${ }^{3}$ PhD. Pharmacist. UFCSPA. VIVAVOZ. ${ }^{4}$ PhD, MD. UFCSPA. VIVAVOZ.
}

This study is part of the dissertation entitled "Características de fumantes associadas à adesão ao tratamento e à mudança de comportamento," presented in 2010 at Universidade Federal de Ciências da Saúde de Porto Alegre (UFCSPA), Porto Alegre, RS, Brazil.

Financial support: Secretaria Nacional de Políticas sobre Drogas (SENAD) and Associação Mário Tannhauser de Ensino, Pesquisa e Assistência (AMTEPA). H.M.T.B. receives a $1 \mathrm{C}$ Research Productivity grant from Conselho Nacional de Desenvolvimento Científico e Tecnológico (CNPq).

Submitted Feb 09 2012, accepted for publication May 24 2012. No conflicts of interest declared concerning the publication of this article.

Suggested citation: Pires GN, Figueiró LR, Ferigolo M, Barros HM, Dantas DC. Tobacco chippers seeking assistance for smoking cessation: a case series. Trends Psychiatry Psychother. 2012;34(4):234-7. 


\section{Introduction}

Tobacco chippers (TCs) are a distinctive group among light smokers. TCs are individuals who have smoked one to five cigarettes per day, for at least four days a week, for two years or more. ${ }^{1}$ This group is less prone to developing nicotine dependence or withdrawal symptoms, ${ }^{2,3}$ and accounts for around $4 \%$ of all current smokers. ${ }^{4}$

Typically, light smokers and TCs are excluded from smoking cessation studies due to the belief that they could easily quit smoking and are at a low risk for experiencing harmful effects. ${ }^{5}$ Therefore, there are few reports assessing TCs who attempt to quit smoking. Light smokers are also prone to tobacco-related diseases, although to a lesser degree when compared with heavy smokers. ${ }^{6,7}$ This fact underscores the importance of investing in smoking cessation and understanding the smoking habits of this population.

The present article describes three cases of TCs who sought assistance for smoking cessation at a free quitsmoking support group.

\section{Methods}

We examined smokers who participated in a free quitsmoking group therapy program. The program consisted of four weekly group meetings and telephone counseling services. ${ }^{8}$ After signing an informed consent form, smokers answered self-administered questionnaires covering sociodemographic data, perceived health status, and smoking history. The questionnaire also included questions to assess nicotine dependence based on the Brazilian National Household Survey on Drug Abuse (NHSDA), which lists six symptoms of the dependence syndrome and considers as dependent those who endorse at least two of them. ${ }^{9}$ The participants' degree of nicotine dependence was assessed using Fagerström Test for Nicotine Dependence (FTND), which ranges from 0 to 10 points (very low to very high). ${ }^{10}$ Participants' motivational stage was assessed using the Contemplation Ladder, ${ }^{11,12}$ and urinary cotinine concentrations were tested according to the colorimetric technique described by Peach et al. ${ }^{13}$

The study protocol was approved by the Ethics Committee of Universidade Federal de Ciências da Saúde de Porto Alegre (UFCSPA), Porto Alegre, RS, Brazil (protocol no. 219/07). All procedures were performed in accordance with the ethical standards set forth in the Declaration of Helsinki.

\section{Description of cases and results}

Of the 183 smokers who participated in the program, three $(1.6 \%)$ were considered TCs and are described below.

TC no. 1. Female, 55 years old, divorced, elder care professional. She had been a smoker for 40 years. Several years ago, she used to smoke 15 cigarettes daily, but more recently she smoked only three cigarettes per day and could not quit. She had attempted quitting several times, and her most successful attempt was a period of abstinence of 30 days during a pregnancy. Currently, she smokes at specific situations, e.g., in the evenings, on her way home. She reported occasional use of alcohol and complained of circulatory problems. Questionnaire information: NHSDA $=3$ criteria; FTND score $=1$ (very low); Contemplation Ladder status $=$ preparation. Cotinine urinary concentration $=2.37 \mu \mathrm{g} / \mathrm{mL}$.

TC no. 2. Female, 27 years old, single, lawyer. She had been smoking five cigarettes per day since she was 14 years old. She was able to quit once, for 30 days, but had strong cravings. She reported using alcohol on the weekends and marijuana on a daily basis. She noticed the consequences of tobacco use on her physical performance and associated smoking with allergic rhinitis crises. Questionnaire information: NHSDA = 4 criteria; FTND score $=1$ (very low); Contemplation Ladder status $=$ action. Cotinine urinary concentration $=3.46 \mu \mathrm{g} / \mathrm{mL}$.

TC no. 3. Female, 51 years old, married, unemployed. She reported smoking for 35 years and smoking five cigarettes daily at the time. She tried to quit twice but could not abstain from cigarettes for more than 10 days, despite using bupropion. She reported occasional use of alcohol and no tobacco-related disease. Questionnaire information: NHSDA = 1 criterion; FTND score $=2$ (very low); Contemplation Ladder status = action. Cotinine urinary concentration $=19.9 \mu \mathrm{g} / \mathrm{mL}$.

All three patients dropped out after the first group meeting. Retention rate of non-TCs was $61 \%$ after one meeting.

\section{Discussion}

While examining the profiles of our three TCs, several factors deserve to be mentioned. First, all three individuals were female, which probably reflects the higher prevalence of this smoking pattern among women. Indeed, this finding is in accordance with the last Brazilian nationwide survey on smoking, which showed that light smoking patterns (defined as smoking less than five cigarettes/day) were more prevalent in women (18.3 vs. 
$14.8 \%$ in men). ${ }^{14}$ However, it could also reflect the higher predisposition of women to seek expert health care. ${ }^{15,16}$

The history of these smokers suggests the occurrence of two different smoking patterns among TCs: the "native" and the "converted" patterns. ${ }^{1}$ Two of the three TCs showed a "converted" smoking pattern, i.e., their current cigarette consumption rates dropped from a previously higher level.

According to the FTND, all three TCs showed some level of dependence. Conversely, according to NHSDA criteria, only two TCs were considered dependent. The divergence of results obtained with these instruments may be due to differences in the characteristics assessed by the two scales. TCs are not usually nicotinedependent, ${ }^{2,3}$ but they may have a decreased autonomy to resist smoking. ${ }^{4}$ In fact, these individuals may be lightly dependent smokers, comprising a group that is different from that of social smokers. Moreover, the smoking histories of our three women suggest that these TCs could, in many aspects, be similar to heavy smokers. All reported the use of alcohol, although at low frequencies, which correlates with the criteria for indulgent smoking. ${ }^{17,18}$

Contemplation Ladder results revealed that the three individuals were at advanced motivational stages. TCs can be as motivated as heavy smokers to quit smoking, although the reasons underlying this motivation are not well understood. ${ }^{5}$ We did not evaluate our three women's reasons for trying to quit, but we can assume that antismoking messages present in the media and the fear of acquiring tobacco-related diseases are as motivating for them as they are for heavy smokers. It is well known that light smokers have a higher risk of dying from heart disease, cancer, and other diseases when compared with non-smokers. ${ }^{6,7}$ Two of our cases (TC nos. 1 and 2) reported the presence tobacco-related disease, which suggests that TCs are subject to health problems related to smoking. The lack of autonomy over smoking ${ }^{4}$ may explain why cessation is difficult in this group despite the knowledge of potential harmful effects associated with the habit.

The cotinine levels here described were higher than those reported in previous studies, which can probably be explained by the low sensitivity and specificity of the method here employed. Indeed, colorimetric methods have some limitations; however, they are useful to distinguish between smokers and non-smokers, as well as to show changes in smoking behavior. ${ }^{19,20}$ In TC no. 3 , the levels of cotinine were remarkably higher. Two possible and speculative explanations for this finding can be raised: 1) this volunteer could be exposed to alternative forms of smoking, e.g., passive smoking; or 2) she may have misreported or underestimated her smoking habits.

It is common for heavy dependents to abandon therapeutic group activities when they lapse or fail to quit smoking. As a result, TCs would be expected to better comply with group therapy. ${ }^{5}$ Nevertheless, the fact that all our TCs dropped out early from treatment suggests that even these light smokers experience great difficulty when trying to quit. Moreover, the demand for assistance coming from TCs is extremely low, probably because of a feeling of embarrassment, especially in group therapy, as they understand that their lower cigarette consumption rate makes their problem less severe.

Some considerations should be made regarding the generalizability of our findings. In general, case series are not intended to generalize data, but rather to prove the existence and/or plausibility of a certain unusual condition. In this sense, we believe that the findings here described provide a proof of the existence and plausibility of the following facts: 1) TCs intend to and perform concrete acts to quit smoking; and 2) TCs are able to motivate themselves to quit smoking. These are, under no circumstances, generic data; nevertheless, similar findings had never been described in the literature.

In short, this study describes a subgroup of smokers that has not been extensively investigated in the literature, namely, TCs seeking assistance for smoking cessation, presenting some degree of nicotine dependence, and who did not adhere to regular group therapy. We suggest that interventions specifically aimed at this population are needed, e.g., support groups for TCs only.

\section{References}

1. Shiffman S, Paty J, Kassel J, Gnys M, Zettler-Segal M. Smoking behavior and smoking history of tobacco chippers. Exp Clin Psychopharmacol. 1994;2:126-42.

2. Shiffman S, Paty JA, Gnys M, Kassel JD, Elash C. Nicotine withdrawal in chippers and regular smokers: subjective and cognitive effects. Health Psychol. 1995;14:301-9.

3. Shiffman S. Tobacco "chippers" - individual differences in tobacco dependence. Psychopharmacology (Berl). 1989;97:539-47.

4. Wellman RJ, DiFranza JR, Wood C. Tobacco chippers report diminished autonomy over smoking. Addict Behav. 2006;31:717-21.

5. Okuyemi KS, Harris KJ, Scheibmeir M, Choi WS, Powell J, Ahluwalia JS. Light smokers: issues and recommendations. Nicotine Tob Res. 2002;4 Suppl 2:S103-12.

6. Bjartveit K, Tverdal A. Health consequences of smoking 1-4 cigarettes per day. Tob Control. 2005;14:315-20. 
7. Luoto R, Uutela A, Puska P. Occasional smoking increases total and cardiovascular mortality among men. Nicotine Tob Res. 2000;2:133-9.

8. Barros HM, Santos V, Mazoni C, Dantas DC, Ferigolo M. Neuroscience education for health profession undergraduates in a call-center for drug abuse prevention. Drug Alcohol Depend. 2008;98:270-4.

9. Carlini EA, Galduróz JCF, Noto AR. II Psychotropic drug use in Brazil: a household survey in the 108 largest cities of the country - 2005. Brasília: Secretaria Nacional Antidrogas; 2007.

10. Fagerström KO. Measuring degree of physical dependence to tobacco smoking with reference to individualization of treatment. Addict Behav. 1978;3:235-41.

11. Biener $L$, Abrams DB. The Contemplation Ladder: validation of a measure of readiness to consider smoking cessation. Health Psychol. 1991;10:360-5.

12. Terra MB, Silveira DX, Moreira TC, Ferigolo M, Mazoni C, Arena FX, et al. Convergent validation study of the Contemplation Ladder for application via telephone in tobacco users. J Bras Psiquiatr. 2009;58:143-9.

13. Peach H, Ellard GA, Jenner PJ, Morris RW. A simple, inexpensive urine test of smoking. Thorax. 1985;40:351-7.

14. Brasil, Instituto Nacional de Câncer, Organização PanAmericana da Saúde. Pesquisa especial de tabagismo (PETab): relatório Brasil. Rio de Janeiro: INCA; 2011.

15. Shiffman S, Brockwell SE, Pillitteri JL, Gitchell JG. Individual differences in adoption of treatment for smoking cessation: demographic and smoking history characteristics. Drug Alcohol Depend. 2008;93:121-31.
16. Szklo AS, Otero UB. Profile of smokers not searching for smoking cessation intervention in Rio de Janeiro, Brazil. Rev Saude Publica. 2008;42:139-42.

17. Epstein AM, Sher TG, Young MA, King AC. Tobacco chippers show robust increases in smoking urge after alcohol consumption. Psychopharmacology (Berl). 2007;190:321-9.

18. Shiffman S, Paty J. Smoking patterns and dependence: contrasting chippers and heavy smokers. J Abnorm Psychol. 2006;115:509-23.

19. Okayama A, Sato T. Assessment of smoking status among workers using an improved colorimetric method. Ind Health. 2004;42:348-51.

20. Smith RF, Mather HM, Ellard GA. Assessment of simple colorimetric procedures to determine smoking status of diabetic subjects. Clin Chem. 1998;44:275-80.

\section{Correspondence}

Luciana Rizzieri Figueiró

Division of Basic Health Sciences, VIVAVOZ Call Center

Universidade Federal de Ciências da Saúde de Porto Alegre (UFCSPA)

Sarmento Leite, $245 / 316$

90050-170 - Porto Alegre, RS - Brazil

Tel./Fax: +55-51-3303-8764

E-mail: rizzieri@ufcspa.edu.br 